\title{
The Structural Form and Development of Cable-Stayed Bridge
}

\author{
BaoChu Yu, a , JiaSong Wang ${ }^{1, b}$, Jie $\mathrm{Ai}^{1, \mathrm{c}}$, RongYang Sun ${ }^{2, \mathrm{~d}}$ \\ ${ }^{1}$ Da lian Ocean University, Dalian, Liaoning province, China \\ 2 No.3 Engineering Company Ltd.Of CCCC First Harbor Engineering Company Ltd.,China \\ abaochuyu@dlou.edu.cn,b1255613005@qq.com,caijiesan@163.com, ${ }^{d}$ sunrongyang@163.com
}

Keywords: cable-stayed bridge; structural form; cooperative system; development

Abstract. This paper introduces the whole development process of cable-stayed bridge from 1955 to nowadays, and analyzes the characteristics of various cable-stayed bridges, such as Cable-stayed Suspension Bridge System, cooperative system of cable-stayed bridge and continuous beam, combination system of cable-stayed bridge and arch bridge and so on. Give an introduction and an evaluation to the cable-stayed bridges which had been built at home and abroad.

\section{Introduction}

Because of the small size of the beam, its good ability to span, wind stability is better than suspension bridge, cable-stayed bridge has been paid highly attention. In order to combine the local natural environment and achieve the desired design style and use requirements, under the efforts of bridge designers, numerous characteristic structural form of cable-stayed bridges have been built.

\section{The development of modern cable-stayed bridge}

The first cable-stayed bridge in the world was the Stromsund bridge in Sweden built in 1955, the span of the bridge is $74.7+182+74.7$, gate-type tower, cables distribute in radiation shape, and the stiffening girder consists of two plate girders. From then on, the cable-stayed bridge has entered a period of rapidly development. Severin bridge built in Cologne, Germany in 1959, its span was 302 meters, use the "A" type tower, and it was the first time to use "floating system" on deck, it also presented an effective solution to the seismic performance of cable-stayed bridges. The maracaibo bridge built in Venezuela in 1962 was the first concrete cable-stayed bridge in the world, its span was 135 meters. The Knie bridge built in Germany in 1969 was the first cable-stayed bridge with hybrid girder, its span was 320 meters.

Since the mid-1970s, with the development of design theory, the growing update of computer technology, the emergence of new materials, and the progress of construction technology, the development of cable-stayed bridge has entered a new era. The Saint-Nazaire bridge in France had been completed in 1975, which main span was 404 meters, this means that the main span of the cable-stayed bridge has begun to break the 400 meters mark.

Entering the 1990s, the long-span cable-stayed bridge with a main span of more than 400 meters is developing rapidly. Because of its attractive appearance, strong span ability, flexible span arrangement, convenient construction, and great mechanical properties, cable-stayed bridge has strong competitive ability which span are from 200 meters to 800 meters. The Normandy bridge built in France in 1995, its span was 856 meters, mixed structure of main beam, once became the world's first cable-stayed bridge.

Now, cable-stayed bridge is still develop continuously, the span is more and more long. Up to now, the Russky Island Bridge in Russia is the longest span cable-stayed bridge all over the world.

\section{The structural form of cable-stayed bridge}

Cable-stayed suspension system bridge. Cable-stayed suspension system bridge was born in the early 18 th century, at that time span is only about 100 meters, so it not being noticed by the world. The suspension part of cable-stayed suspension system bridge is quite smaller than the same span in 
suspension bridge, it can reduce main cable force, reduce the costs of main cable and anchorage, when construction, the cantilever length of cable-stayed part can greatly reduce, and it is helpful to improve the wind resisting stability of the structure and the completion state. In the design of the Gibraltar Strait bridge has this kind of cable-stayed suspension system.

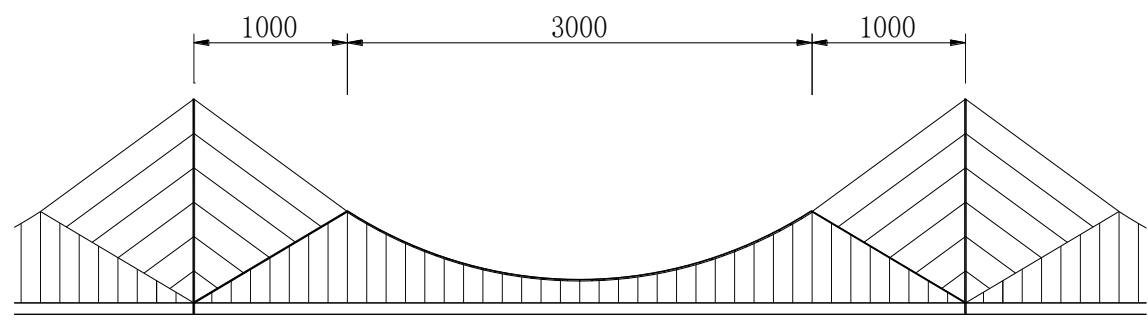

Fig. 1 The Gibraltar Strait bridge

Combination system of cable-stayed bridge and arch. Combination system of cable-stayed bridge and arch always uses to build air port bridge in Japan. Because of the limitation of terrain conditions, it is not possible to construct a single pylon or twin towers cable-stayed bridge in the width of the air port, so designers have adopted an arch tower cable-stayed bridge which can across the airport. Dalian University of Technology designed a novel combination system of cable-stayed bridge and arch for the Xinhua Crossroad bridge in Yingkou, Liaoning province. It use cable-stayed to pull the arch-rib, and set rigid rod into the arch-rib. This innovative design combined with existing bridge structure form skillfully, and blend into the local custom.

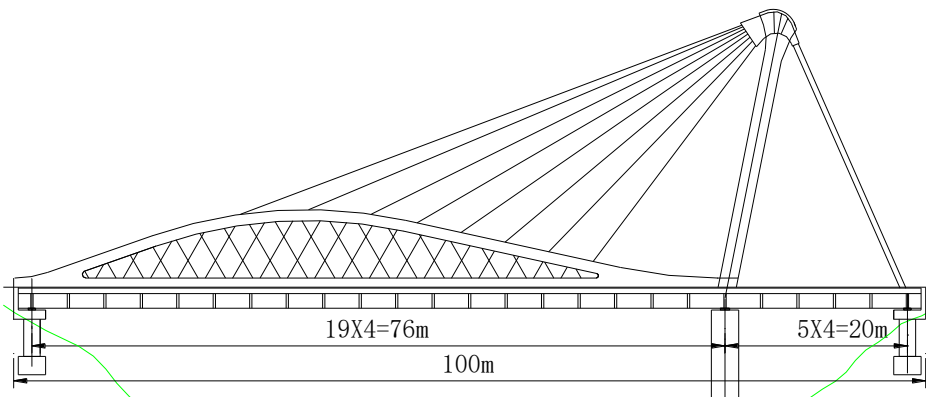

Fig. 2 The Xinhua Crossroad bridge in Yingkou

Cooperative system cable-stayed bridge. Cooperative system cable-stayed bridge is a kind of cable-stayed bridge that combine with continuous beam on one sides or two side, rigid frame, and other system bridge. Such as the famous Sunshine-Skymay bridge in America, P-K bridge, and East-Hungting, these cooperative system are all cable-stayed bridge and continuous beam, in fact is added a long cable free zone on the two sides of the cable-stayed bridge and connect with continuous beam.

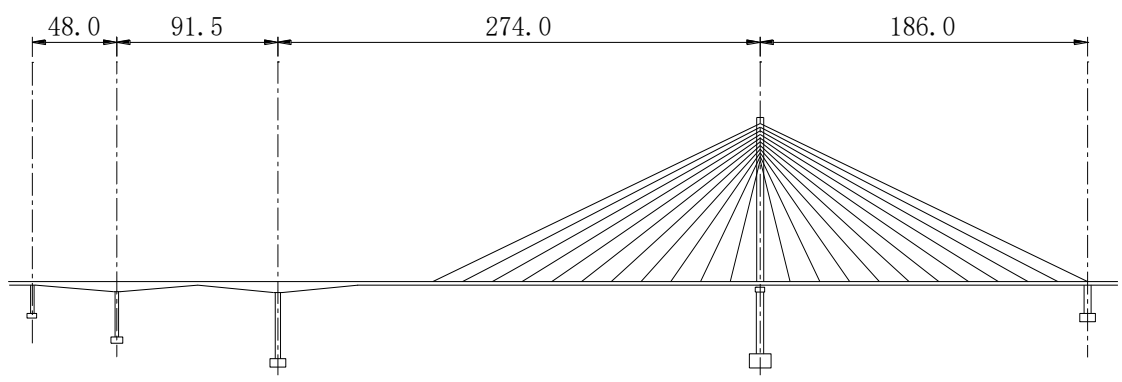

Fig. 3 The East-Hungting bridge 
All over the world, we can see that the construction of cooperative system cable-stayed bridge is not too much. People are used to add a long cable free zone on the two sides of the cable-stayed bridge to increase the span, and the cooperative system cable-stayed bridge is not considered as a mainstream method, the main reason is that when the span is large, bridge designers are easy to think of the twin towers cable-stayed bridge or steel cable-stayed bridge. Although these methods can solve the needs of span, the cost will increase relatively. Especially, the steel structure material is expensive in China, construction of concrete cable-stayed bridge is the first choice.

Guangdong Jinma bridge is a kind of special cooperative system of T-shape steel structure and single -tower cable-stayed bridge. It is the first time that this structure is put forward and applied to the actual construction of large bridges in the world. It is not like the East-Hungting bridge in the United States, but the real use of the two kinds of structural system of "cooperation".

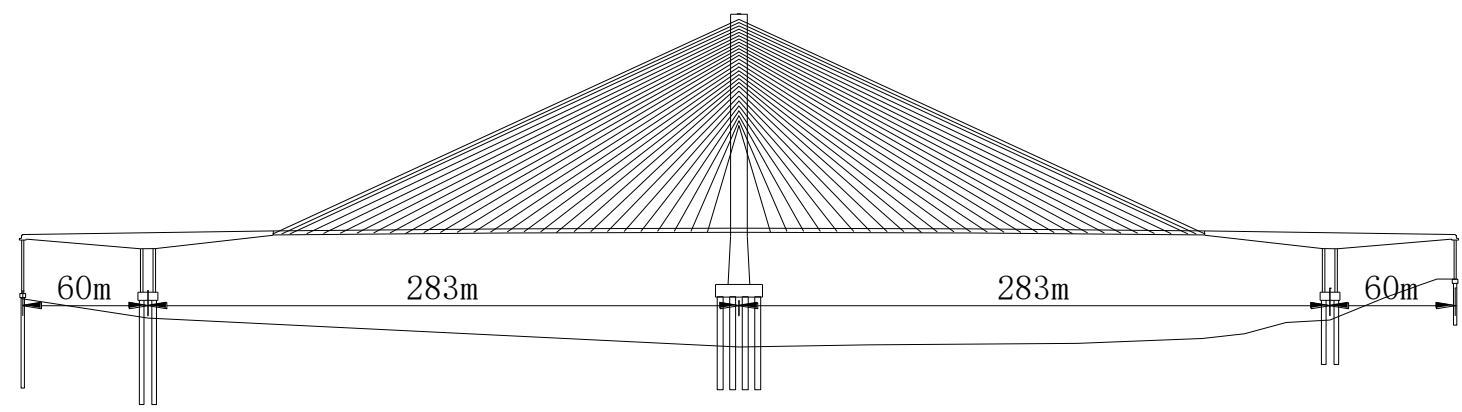

Fig. 4 The Jinma bridge

Other forms of cable-stayed bridge. The Alamillo bridge in Seville, Spain, which across the Guadalquivir River, it is a cable-stayed bridge with bold design, special shape and novel structure. This bridge is a single span cable-stayed bridge, the tower leans back, without dorsal cable, once has attracted the attention of the world bridge community. This bridge has another different place, its sidewalk is in the middle of the bridge, and higher than both sides of the road, this will increase the stiffness of the main beam.

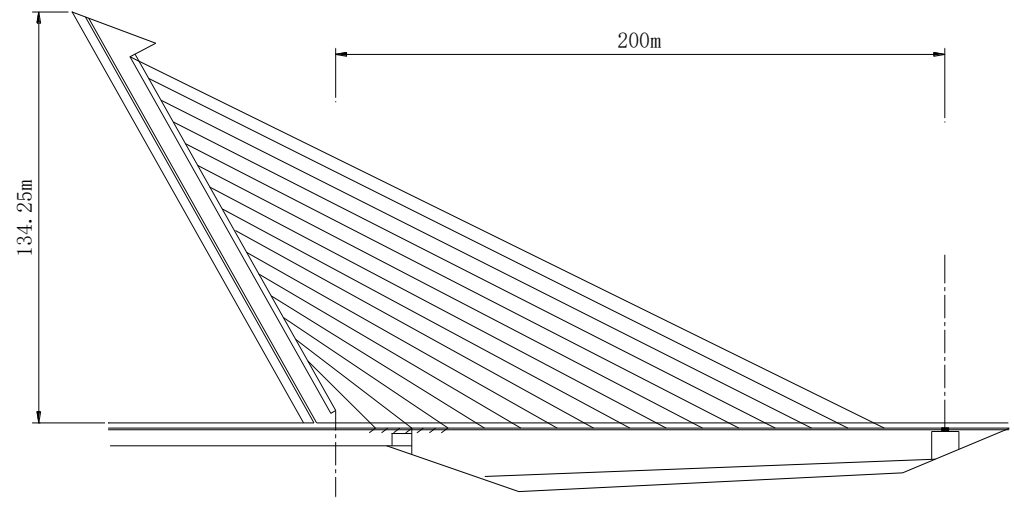

Fig. 5 The Alamillo bridge

Many designers make tower as the symbol construction of a cable-stayed bridge, so the appearance and the innovation of the tower is the key to cable-stayed bridge design. The Houston bridge in the United States is a form of two bridges are in parallel, its bridge tower is made of double diamond structure parallel formed by connecting, and its appearance is novel and unique. 

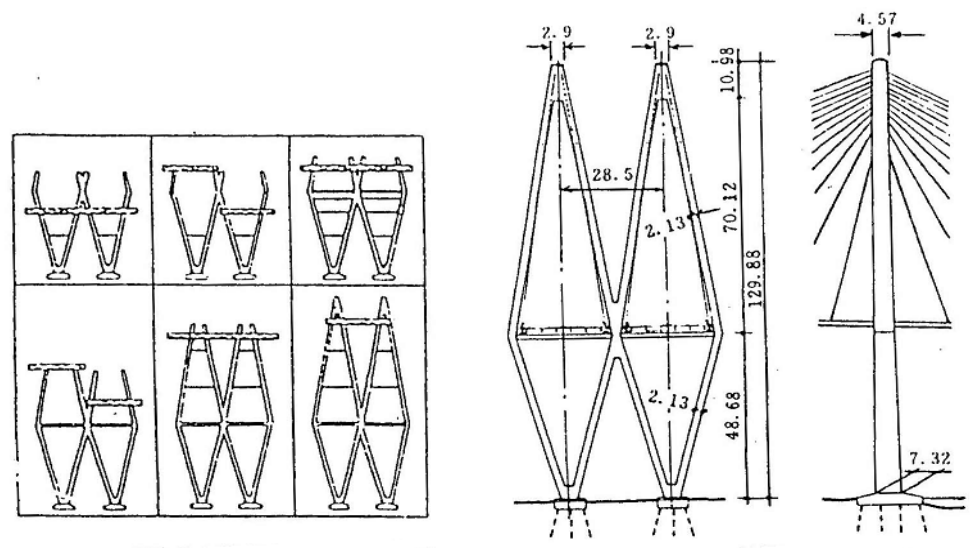

Fig. 6 The tower of the Houston bridge

\section{Conclusion.}

Cable-stayed bridge develop till now, great progress has been made in the efforts of the people, but there are still some aspects can be improved. Such as research and develop new materials to reduce the dead-weight of super large span cable-stayed bridge structure; research on construction technology; improvement of construction process control system and so on. I hope in the near future, cable-stayed bridge technology will have a leap.

\section{References}

[1] Lei Junqing, Zheng Mingzhu. Suspension bridge design [M]. Beijing: China Communications Press, 2002.

[2] Qian Dongsheng, Chen Renfu. Design and construction of long span suspension bridge [M]. Southwest Jiao Tong University press, 1999.

[3] Zhang Yuankai, Xiao Rucheng. Self anchored suspension bridge conceptual design [J]. Highway, 2002, Vol. 11, p. 46-49.

[4] John A.Ochsendorf.Divid P.Villington. Self-anchored suspension bridges [J]. Journal of bridge engineering, 1999,Vol.4, p.155 156.

[5] Zhang Zhe, Dong Peng, Shi Lei, Liu Chuncheng. A review of the development of concrete self anchored suspension bridge [J]. World Bridge, 2003, Vol.1, p.4 9.

[6] Kiureghian A D, Neuenhofer A. Response spectrum method for multi-support seismic excitaions[J]. Earthquake Engineering and Structural Dynamics, 1992, Vol.21, p.713 740.

[7] Kiureghian A D, Neuenhofer A. A discussion on seismic random vibration analysis of multi-support seismic excitaions [J]. Journal of Engineering Mechanics, 1995, Vol.121, p.1037.

[8] Ernesto H Z, Vanmarcke E H. Seismic random vibration analysis of multi-support structural systems [J]. ASCE, Journal of Engineering Mechanics, 1994, Vol.120, p.1107 1128. 